\title{
Union members at the polls in diverse trade union landscapes
}

Article

Accepted Version

Arndt, C. and Rennwald, L. (2016) Union members at the polls in diverse trade union landscapes. European Journal of Political Research, 55 (4). pp. 702-722. ISSN 1475-6765 doi: https://doi.org/10.1111/1475-6765.12157 Available at https://centaur.reading.ac.uk/72615/

It is advisable to refer to the publisher's version if you intend to cite from the work. See Guidance on citing.

Published version at: http://onlinelibrary.wiley.com/doi/10.1111/1475-6765.12157/abstract

To link to this article DOI: http://dx.doi.org/10.1111/1475-6765.12157

Publisher: Wiley

All outputs in CentAUR are protected by Intellectual Property Rights law, including copyright law. Copyright and IPR is retained by the creators or other copyright holders. Terms and conditions for use of this material are defined in the End User Agreement.

\section{www.reading.ac.uk/centaur}

\section{CentAUR}

Central Archive at the University of Reading

Reading's research outputs online 
European Journal of

Political Research

Union members at the polls in diverse trade union landscapes

\begin{tabular}{|r|l|}
\hline Journal: & European Journal of Political Research \\
\hline Manuscript ID & EJPR-2015-0294.R1 \\
\hline Manuscript Type: & Original Manuscript \\
\hline Keywords: & Trade unions, Voting behaviour, Social democracy \\
\hline \multicolumn{2}{|c}{} \\
\hline
\end{tabular}

SCHOLARONE ${ }^{m}$

Manuscripts 


\section{Union members at the polls in diverse trade union landscapes}

(Word count: 8'528 without this line) 


\section{Introduction}

Historically, trade unions and social democratic parties were closely linked. They find their origins in the same movement. Social democratic parties acted as the political arm of the labour movement, while unions were the economic arm of the labour movement (Ebbinghaus 1995). Over the last years, the relationships between these two components were far from harmonious (e.g. Allern, Aylott \& Christiansen 2007), even leading in some countries to the formation of new parties, for example Die Linke in Germany (e.g. Nachtwey \& Spier 2007). While many recent contributions have focused on the difficulty for social democratic parties to mobilize their working-class constituencies (e.g. Arndt 2014, Arzheimer 2013, Gingrich \& Häusermann 2015, Rennwald 2015), little is known on the support from trade union members.

Does social democracy still benefit from the support of this core clientele and which competitors does it face? This article proposes the first updated comparative analysis on the voting choice of union members in Western Europe. Despite the significant decrease of unionization in industrialized countries (see Pontusson 2013), union members still do represent a non-negligible share of the electorate (e.g. 17.7\% of wage-earners in Germany, $25.4 \%$ in United Kingdom or $66.8 \%$ in Denmark (OECD.Stat 2013)) ${ }^{1}$. As Streeck and Hassel (2003) notice, social democratic parties have often tried not to appear too close to trade unions, but at the same time still need the support of this constituency to win elections.

Two elements require a careful investigation. On the one hand, European party systems have grown more diverse with the rise of new left-wing parties (Greens and radical left) and radical right-wing parties. While the literature on electoral realignments and class voting has long taken this new configuration into account (for a literature review see Häusermann, Picot \& Geering 2013), we do not have much information on the behaviour of union members in transformed party systems. On the other hand, with the change of the employment structure, unions organize not only the manual workers, but also increasingly (albeit not without difficulty), the higher-skilled white-collar workers. The organization of white-collar workers displays a strong cross-national variation. As put it by Ebbinghaus and Visser (2000: 54), "between countries with similar transformations in the class structure and similar shares of white-collar employment, we find significant differences in the pattern of organization and affiliation of white-collar employees and their unions". However, to our knowledge, no

\footnotetext{
${ }^{1}$ Ebbinghaus et al. (2011) present an excellent overview on the determinants of cross-national variation in union membership in Europe.
} 
comparative analysis has ever examined the effect of the diversified union landscape on electoral behaviour.

We therefore argue that the structure of the trade union movement represents an important (but of course not the sole) variable conditioning the impact of union membership on voting choice. More specifically, the relative strength of the different trade union confederations moderates the effect of union membership. The support of union members for social democracy is fostered by the strength of the confederations historically close to this party family, while it is hampered when strong separate (or politically unaffiliated) whitecollar confederations exist. This specific variation highlights some opportunities and limitations (among many others) for the labour movement in times of changing employment structure.

The present article delivers above all an empirical contribution given the aim of providing a European overview on the topic. It contributes also to the debate on the future of social democracy (see Kitschelt 1994). A careful investigation of changes in class cleavage requires not only the study of its social basis, but also of its organizational component, and how the two might evolve independently from one another (Bartolini \& Mair [2007] 1990: 202-203). By studying the persistence or break of the party-union linkage in the electoral arena, this study constitutes a first step towards this ambitious goal.

The paper is structured in the following way. The first two sections discuss the relevant literature on organized labour and present the hypotheses, first related to party system, second related to union structure. After the research design, the first empirical section presents the voting choice of union members in Europe and how it is conditioned by union structure. In the second empirical section, we show with Sweden as an illustrative case that the presence of specific white-collar confederations does not always bring an electoral advantage for social democracy.

\section{The distinct vote choice of union members in a new party landscape}

A vast literature deals with the impact of unionization on the decision to participate in elections (for a literature review, see Pontusson 2013: 807-809). By contrast, only few (recent) studies have dealt in depth with the effect of union membership on party choice, mainly outside Europe (e.g. Freeman 2003, Leigh 2006) and based on single case studies (see for France Parsons 2015, for UK Quinn 2010). 
Why should union members be more likely to support specific parties? It is possible to consider this question under several perspectives. Firstly, the vote of union members can be understood as the product of the specific relationship between the two arms of the labour movement (social democratic party and trade union). Changes in this relationship should be reflected at the level of individual voting behaviour. Secondly, it is possible to emphasize the political attitudes of union members making them more likely to support specific parties. Thirdly, as unions represent the organizational component of the class cleavage (Bartolini \& Mair [2007] 1990), it is possible to emphasize the parties' positioning and strategies on socioeconomic issues and their potential impact on union members voting choice (for the "topdown" approach on social class, see Evans \& De Graaf 2013). We briefly discuss these three elements and derive our hypotheses.

There is a widespread impression that the relationships between social democratic parties and trade unions have changed over the last years. However, the systematic empirical studies conducted display a nuanced picture. In Scandinavia for example, Allern et al. (2007) find deep changes in Denmark, but not in Norway or Sweden. Reviewing existing studies, Allern and Bale (2012: 14) emphasize the strong cross-national variation in the changes of party-union relations, and more generally the strong variety of linkages at stake. In their study on unions in ten Western European countries, Gumbrell-McCormick and Hyman (2013: 138) also come to a similar conclusion: even though the authors emphasize the fragility of partyunion ties, there is in their view "no uniform process of distancing or divorce but strong crossnational variation".

Scholars have demonstrated the specific political attitudes of union members. Mosimann and Pontusson (2014) show that union members are more likely to support redistribution than other citizens. The effect is not due to the fact that individuals supporting redistribution are more likely to join unions. The authors convincingly show that there is a clear direction in this relationship. The fact of being member of a trade union generates a sense of solidarity with individuals of different income levels. Based on this, union members should be more likely to support parties advocating redistributive policies, which is the historical legacy of left-wing parties. But to what extent do social democratic parties benefit from a clear advantage compared to their competitors of the left-wing camp? Let's now discuss the positioning and strategies of parties on socio-economic issues.

The growing competition of radical left-wing parties is in some countries directly related to divergences between social democratic parties and unions. The latter went to 
increasingly criticize the political choices of social democratic parties, this especially when they were in power in several Western European countries in the late 1990s and beginning 2000s. Thus, we expect social democratic parties to be in fierce competition with radical leftwing parties among union members. By contrast, the Greens find their origins in the criticism of the Keynesian (productivist) class compromise of the Post-World War advocated by both social democratic parties and unions (see Sassoon 1996: 647-690). For the former, this economic model promoted employment and growth, while for the latter it posed a threat to natural resources. Over the years, the labour movement went to integrate issues related to sustainable development. Yet, this difference in origins might still have some impact, particularly when issues of employment are in conflict with environmental issues. So, we expect trade union members to be relatively more likely to support social democratic parties than Green parties.

Union members should be less likely to support right-wing parties. Similar partyinterest group linkages have developed between conservative/liberal parties and employers' associations. However, recent literature has shown how radical right-wing parties strategically blur their positioning on economic and social policy (Rovny 2013, Afonso 2015). This strategy might allow radical right-wing parties to appear less as the arm of employers as compared to mainstream conservative and liberal parties. Based on the combination of the three elements discussed, we test the following hypotheses:

H1: Union members are generally more likely to vote for social democratic parties than to vote for other parties.

H2a: The effect of union membership is stronger in the contrast with the mainstream rightwing parties than in the contrast with radical right-wing populist parties.

H2b: The effect of union membership matters in the contrast with the Greens, but there is no difference with radical left-wing parties.

\section{The impact of union membership in diverse union structures}

We have started from the idea that unions represent the economic arm of the labour movement. However, there exists a large variety of unions with different political conceptions and linkages with political parties, without mentioning the presence of Communist dominated unions in countries where the left was divided and the variety of (social democratic or labour) party-union relationships (Ebbinghaus 1995). Historically, Christian unions had developed as 
competitors of the socialist labour movement inside the working class (Pasture 2002). Additionally, white-collar unions have formed in several countries in order to represent the interests of white-collar workers, seen as distinct from those of blue-collar workers.

Taking into account this diversity, we therefore argue that the impact of union membership on voting behaviour is conditioned by the union structure existing in a country. The support for social democracy is likely to be affected by the strength of the different confederations. We focus here on the level of confederations, since the more or less formalized relationships between political parties and unions take generally place at this level. Not all confederations have the same linkages with social democratic parties. Moreover, some confederations organize specific segments of the workforce and this might impact on the conceptions of solidarity among their members. This element takes an increasing importance with the growth of white-collar employment.

With its "most class-segmented union movement in the world" (Kjellberg 2013: 6), the Swedish case illustrates very well the challenges that the socialist labour movement faces. The blue-collar union confederation (LO), which is close to the Swedish social democratic party (SAP), has lost relatively weight within the union movement. While LO organized 78\% of all union members in Sweden in 1950, it organizes only $44 \%$ of union members in 2013 , the lowest share ever reached (Kjellberg 2013: 8). The shift has helped the growth of two other confederations, the university-educated professionals (Saco) and the other white-collar workers (TCO). In 2013 Saco organizes 17\% of all union members, while TCO organizes $36 \%$. Both confederations stress their political independence, but historically the SAP had closer links to the TCO than to the Saco.

The existence of separate confederations based on class constitutes an extreme case that can be found above all in Scandinavia. An intermediate case would be that both blue-collar and white-collar unions co-exist, but that they are reunited in the same confederation. At the other end, the most cohesive representation of all wage-earners exists in the case of vertical unions (industrial unionism), with all wage-earners of a company organized in the same union, irrespective of their class or function (Höpflinger 1980: 37-38). The presence of separate confederations does not mean that they are necessarily adversary, but it indicates nevertheless a need for a certain differentiation in the representation of wage-earners.

Scholars have warned against overestimating the peculiarities of white-collar unionism which is very diverse (e.g. Blackburn \& Prandy 1965, Crompton 1976). However, they have also emphasized some distinct characteristics of white-collar unions especially when they 
organize wage-earners of a specific profession. In this case, they come closer to professional associations whose one characteristic is to "restrict entry to a profession in order to protect its status and prevent downwards wage pressure" (Kjellberg 2013: 35). Moreover, when they organize exclusively wage-earners with a higher status or a position close to the management, unions can develop a different ideological profile with a less contentious vision of the employment relations, more emphasis on representation than bargaining and a lower level of militancy (Blackburn \& Prandy 1965). A recent study on the confederation of managerial staff in France (CFE-CGC) shows well the collaborative vision of union work among the members, as well as the reticence of the use of the strike (Béthoux et al. 2013).

A decisive contribution by Mosimann and Pontusson (2014) indicates that the members' composition of unions affect the conception of solidarity of their members. Interested in the effect of union membership on support for redistribution, the authors show that union membership makes above all a difference for high-income individuals. It matters less for lowincome individuals who have a strong self-interest in redistribution. However, among highincome individuals, the effect of union membership is stronger when unions encompass a large range of incomes. The authors suggest the following underlying mechanism: members of encompassing unions will more often meet and share experiences with people of different income levels and occupations thus generating more solidarity. By contrast, if unions organise a more limited range of incomes, their members will develop a more narrow sense of solidarity.

In this respect, we expect that the confederations grouping together academic and professionals (for example Saco in Sweden) will not have the same effect on voting behaviour as compared to the confederations historically close to the social democratic parties. Not only do the professional confederations lack organizational linkages with the social democratic parties, but they will also foster self-interest rather than large-scale solidarity with low incomes. This will open the way for typical competitors of social democracy among the middle class, the Greens and the centre-right parties. The impact of union membership on voting choice will be therefore conditioned by the strength of the different confederations within the trade union movement. The support for social democracy will be fostered by the strength of the confederations historically close to this political family. The following hypotheses are tested:

H3: The effect of union membership on voting social democracy increases with the membership share of the union confederation historically close to the social democratic party. 
H4: Strong independent academic and professional union confederations reduce the vote of union members for social democracy, but increase the vote for centre-right and green parties.

\section{Research design and data}

We combine a comparative study of 16 European countries in 2002-2010 with a crosstemporal case study of Sweden in the period 1986-2012. ${ }^{2}$ The comparative study allows testing the effect of union membership (micro-level) in diverse union structures (macro-level) with multilevel models. Given the differences in historical trajectories, we focus on West European countries. For union structure, we make use of the Jelle Visser's (2013) data base Institutional Characteristics of Trade Unions, Wage Setting, State Intervention and Social Pacts, 1960-2011 (ICTWSS). We then combine it with the European Social Survey (ESS) ${ }^{3}$ 2002-2010 which contains an item on current union membership and various controls. It also allows operationalizing class position through the Oesch-class schema (Oesch 2006).

In Sweden, we can study the membership in different confederations directly at the micro-level on the basis of the annual Riks-SOM surveys (Weibull et al. 2014). The crosstemporal case study therefore provides a second test of our hypotheses to substantiate the results of the multilevel models. In the comparative study, we show that the strength of professional/academic confederations plays at the disadvantage of social democracy. With the case study, we can show more in detail with whom social democracy is in competition, this over a long time period. The Swedish case is also important from a substantial point of view. It demonstrates well the importance of making further differentiations across union confederations. This holds particularly true for Scandinavian countries where class-based confederations exist in a high union density context fostered by the Ghent unemployment insurance system ${ }^{4}$ (Ebbinghaus, Göbel \& Koos 2011).

\section{Operationalization of union structure with the ICTWSS data}

We coded the different union confederations (peak organisations) in every country into six categories. We then calculated the share of the union members organized through the confederation as their strength and as measure for union structure. The six categories are "social democratic", "public sector/white-collar", "academic/professional", "Christian",

\footnotetext{
${ }^{2}$ We analyse Austria, Belgium, Denmark, Finland, France, Germany, Ireland, Italy, Luxembourg, the Netherlands, Norway, Portugal, Spain, Sweden, Switzerland, and the UK.

${ }^{3}$ Further details and documentation are available at http://www.europeansocialsurvey.org/

${ }^{4}$ Under the Ghent system, unemployment insurance is predominantly organized by the trade unions and not the state which makes union membership a condition for unemployment benefit eligibility.
} 
"communist", and "other". The categorization includes both the traditional competitors for the labour movement, i.e. the Christian and the communist confederations, as well as the confederations of white-collar workers which are of special interest in this article due to the changes of the employment structure.

The category "social democratic" includes those confederations that have a dominant position within the union system and that are traditionally and predominantly linked to the social democratic party such as the Austrian ÖGB, the British TUC or the Swedish LO. We cannot do full justice to the large diversity of confederations and of their linkages with (social democratic) parties across Europe. For example, in Austria, political factions play an important role within the ÖGB structure (Ebbinghaus 2000: 84-85). In Great Britain, not all TUC member organizations are affiliated to the Labour Party, but it is the case of a large majority of them (representing $69 \%$ of all TUC members).

The category "academic/professional" includes those federations that are not part of the dominant social democratic umbrella organization and (mainly) represent academics, professionals, and executive managers, predominantly in the private sector. The Finnish AKAVA or the Swedish SACO are examples. The public sector confederations are those that are independent of the social democratic confederation and mainly organize white-collar workers in the public sector (for example the German Beamtenbund). In Scandinavia, the confederations of this category bring together both public and private sector white-collar workers (for example the TCO in Sweden). The full classification appears in Table A.1 in the appendix.

The six variables contain thus the share of labour organized under a particular confederation. For instance, the value for the social democratic organization in Austria is 1.00 or $100 \%$ since Austria has only one peak organization which is predominantly close to the social democratic party. The value for academic/professional confederations for Finland is 0.217 or $21.7 \%$ since the independent union confederation AKAVA organized more than every fifth union member in Finland in the period after 2001. For the multilevel analysis, we created cross-level interactions between union membership and our six union confederation measures. The cross-level interactions measure the effect of union membership on party 
choice across the range of the confederation membership share (e.g. from 0 per cent to 25 per cent organized in academic/professional unions). ${ }^{5}$

Figure 1 shows that the composition of trade union membership varies considerably and that there is a certain clustering of countries. Austria is as mentioned before the only country where every union member is member of the same confederation, the ÖGB. The same is virtually true for Ireland and the UK which have no other real competitor to their Trade Union Congresses than minor and non-classifiable confederations. This constellation should therefore have positive effects on the support of union members for social democracy (Hypothesis 3).

Figure 1: Composition of Trade Union Membership over Confederations, 16 European countries, 2002-2010 (averaged)

\begin{tabular}{|l} 
Austria \\
Belgium \\
Switzerland \\
Germany \\
Denmark \\
Spain \\
Finland \\
France \\
UK \\
Ireland \\
Italy \\
Luxembourg \\
Netherlands \\
Norway \\
Portugal \\
Sweden
\end{tabular}

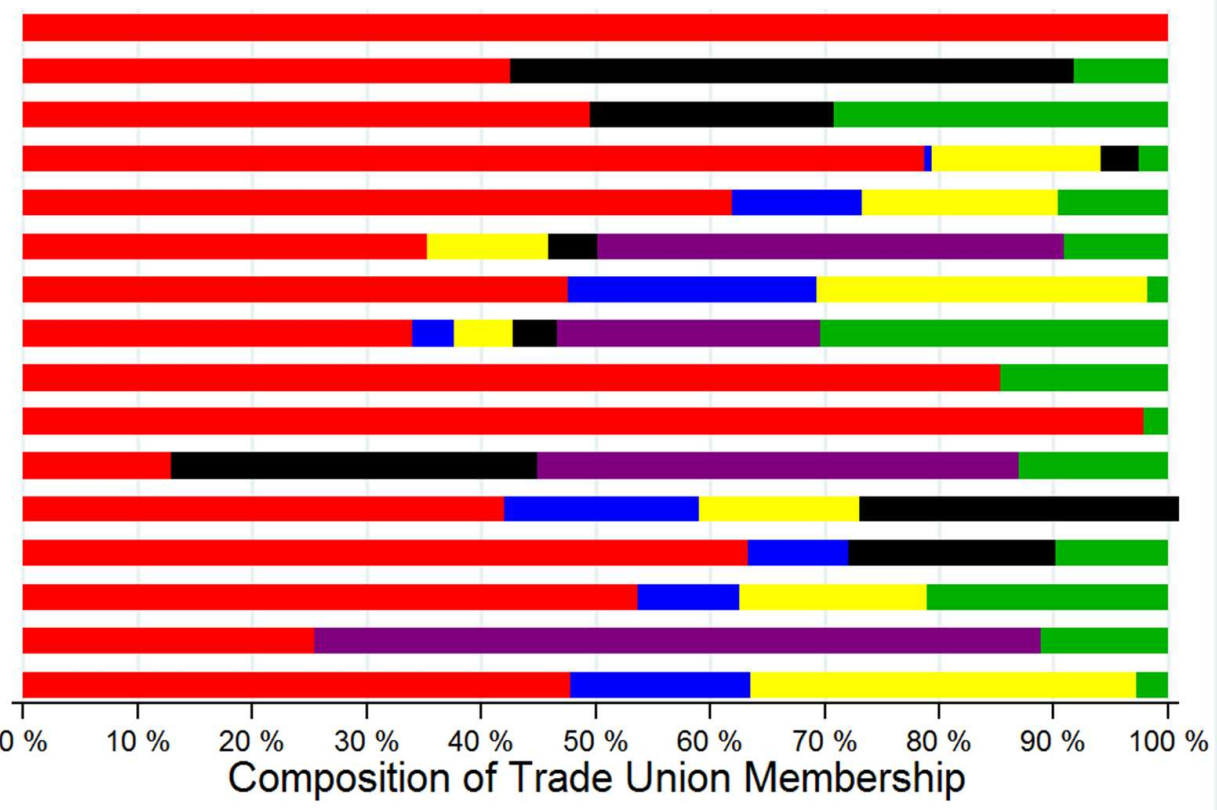

\begin{tabular}{|l|l|}
\hline Share Social Democratic & Share Academic/Professional \\
Share Public Sector & Share Christian \\
Share Communist & Share Other Confederations \\
\hline
\end{tabular}

Source: Own calculations based on Visser (2013). See Table A.1 for classification of individual unions.

The four Nordic countries have all a large confederation organizing 50-60 percent of union members, but also larger public sector and professional confederations that organize

\footnotetext{
${ }^{5}$ Since the six union structure variable represent compositional data, the category 'other' was left out as reference category.
} 
between 10 and 35 percent of the unionized workforce. Especially the presence of strong academic/professional unions should reduce the support for Social democracy (Hypothesis 4). A third cluster concerns the Continental European countries Belgium, Switzerland, Luxembourg and the Netherlands, where a Christian confederation competes with the social democratic confederation. The Mediterranean countries France, Italy, Portugal, and Spain are characterized by the presence of a larger leftist/communist confederation and fragmented union structures.

Case study: Sweden 1985-2010

We use the Swedish Riks-SOM surveys which are annual opinion polls on a variety of economic, social, and political issues conducted since $1986 .{ }^{6}$ We use the "Super Riks-SOM 1986-2012" (SND-0905), a pooled dataset containing all surveys (Weibull et al. 2014). It includes an item that asked the respondents whether they were member of a trade union with four response options 1 "yes, member of a union organized under LO", 2 "yes, member of a union organized under TCO”, 3 “yes, member of a union organized under SACO”, and 4 "not a trade union member". This is to our knowledge the best available item in election studies to capture union membership in different confederations over a longer time span in Western countries. We ran a multinomial logit model with vote choice in election years as dependent variable and interactions between union confederation membership and year as main independent variables (e.g. TCO*year). These results will be presented as predicted party choice over the different union confederations in the period 1985-2010 controlled for class, age, education, sector, and sex.

\section{Comparative analysis of the vote choice of trade union members}

We used a stepwise model building strategy and began with multilevel logit models that contained only individual level variables as well as two basic macro-level controls (union density and Ghent system). We then added our measures for union structure and finally interacted union membership with the three relevant union confederations. We start by examining the vote choice of union members for the different parties (Hypotheses 1 and 2). We then add the cross-level interactions to demonstrate how the vote of union members is conditioned by the strength of the different confederations (Hypotheses 3 and 4). The results for the interactions will be visualised, since their interpretation in logistic models is not

\footnotetext{
${ }^{6}$ The data and further description can be accessed at http://snd.gu.se/sv/catalogue/series/9.
} 
always straightforward (Berry, DeMeritt \& Esarey 2010, Brambor, Clark \& Golder 2006). The coefficients for these models appear in the online appendix.

\section{The continuing preference of union members for the left}

Table 1 presents the results for the effects of union membership and union structure for the party contrasts of interest in Models 1-10 (controlled for class and other demographic controls, not shown $)^{7}$. M1 demonstrate that union members are significantly more likely to support social democratic parties versus all other parties, as was expected in Hypothesis 1. Turning to the different party contrasts, we can see that union members are significantly less likely to vote for centre-right parties over social democratic parties (M3). They are also significantly less likely to support the radical right (M7). The coefficient is even slightly stronger than in the case of the centre-right speaking against Hypothesis 2a.

Union membership significantly decreases the support for the Greens over social democracy (M5), but the effect is weaker than in the case of the centre-right. Contrarily to all other party contrasts examined, the radical left does not show significant differences to social democracy among union members (M9). The disadvantage of the Greens among union members and the competition from the radical left speaks in favour of our Hypothesis $2 b$. Generally, the radical left comes closest to social democracy in its electoral profile, since it has the lowest number of significant predictors in our analysis (also regarding the controls). Finally, looking at the macro-level control of union density, the pattern is the same as for union membership at the individual level.

Next, we briefly examine the models including the trade union structure at the macrolevel (M2, M4, M6, M8, M10). The effect of union membership on party choice remains unchanged. However, it is interesting to note that the significant effect of union density disappears once we introduce the more detailed union structure in M2 (also in M6 and M8). This means that union density alone is no powerful predictor of social democracy's strength once we control for the diversity of trade union confederations.

Always at the macro-level, M2 demonstrate that the strength of the different confederations play a role in the support for social democracy. A high membership share in the confederation traditionally linked to social democracy is significantly beneficial for social democracy, which provides some first evidence for Hypothesis 3. Strong public sector confederations also provide an important mobilisation base for social democracy. In contrast,

\footnotetext{
${ }^{7}$ Full tables appear in the online appendix.
} 
strong academic/professional confederations exhibit a disadvantage for social democratic parties since the coefficient is highly negative in M2, which provides some first evidence for Hypothesis 4. A similar pattern can be observed for the different party contrasts (M4, M6, M8, M10). Strong academic/professional confederations significantly increase the support for the centre-right and the radical right, while public sector confederations significantly decrease the vote for the centre-right and the Greens. Strong social democratic confederations significantly decrease the support for the Greens and the radical right, but have no significant effect in the case of the centre-right. 
Table 1: Union membership, union structure, and vote choice, 2002-2010 in 16 Western countries

\begin{tabular}{|c|c|c|c|c|c|c|c|c|c|c|}
\hline & \multicolumn{2}{|c|}{ SD vs. all other } & \multicolumn{2}{|c|}{ Centre-right vs. SD } & \multicolumn{2}{|c|}{ Greens vs. SD } & \multicolumn{2}{|c|}{ Radical right vs. SD } & \multicolumn{2}{|c|}{ Radical Left vs. SD } \\
\hline & M1 & M2 & M3 & M4 & M5 & M6 & M7 & M8 & M9 & M10 \\
\hline Union member & $\begin{array}{l}0.479 \\
(0.021)^{* * *}\end{array}$ & $\begin{array}{l}0.487 \\
(0.022)^{* * *}\end{array}$ & $\begin{array}{l}-0.573 \\
(0.027)^{* * *}\end{array}$ & $\begin{array}{l}-0.586 \\
(0.027)^{* * *}\end{array}$ & $\begin{array}{l}-0.253 \\
(0.040)^{* * *}\end{array}$ & $\begin{array}{l}-0.266 \\
(0.040)^{* * *}\end{array}$ & $\begin{array}{l}-0.609 \\
(0.048)^{* * *}\end{array}$ & $\begin{array}{l}-0.619 \\
(0.048)^{* * *}\end{array}$ & $\begin{array}{l}-0.044 \\
(0.051)\end{array}$ & $\begin{array}{l}-0.043 \\
(0.052)\end{array}$ \\
\hline Constant & $\begin{array}{l}-2.186 \\
(0.230)^{* * *}\end{array}$ & $\begin{array}{l}-3.654 \\
(0.672)^{* * *}\end{array}$ & $\begin{array}{l}1.574 \\
(0.256)^{* * * *}\end{array}$ & $\begin{array}{l}0.973 \\
(0.803)\end{array}$ & $\begin{array}{l}-0.816 \\
(0.563)\end{array}$ & $\begin{array}{l}6.278 \\
(1.525)^{* * *}\end{array}$ & $\begin{array}{l}-0.562 \\
(1.089)\end{array}$ & $\begin{array}{l}13.908 \\
(3.749)^{* * *}\end{array}$ & $\begin{array}{l}-3.964 \\
(0.755)^{* * *}\end{array}$ & $\begin{array}{l}-5.718 \\
(2.510)^{*}\end{array}$ \\
\hline \multicolumn{11}{|c|}{ Macro-level variables: Trade union structure (share of members organised in given federation of all members in per cent) } \\
\hline Union density & $\begin{array}{l}0.018 \\
(0.005) * * *\end{array}$ & $\begin{array}{l}0.007 \\
(0.005)\end{array}$ & $\begin{array}{l}-0.018 \\
(0.006)^{* *}\end{array}$ & $\begin{array}{l}-0.014 \\
(0.006)^{*}\end{array}$ & $\begin{array}{l}-0.032 \\
(0.009) * * *\end{array}$ & $\begin{array}{l}0.000 \\
(0.012)\end{array}$ & $\begin{array}{l}-0.064 \\
(0.014)^{* * *}\end{array}$ & $\begin{array}{l}0.027 \\
(0.025)\end{array}$ & $\begin{array}{l}-0.018 \\
(0.011)\end{array}$ & $\begin{array}{l}-0.027 \\
(0.020)\end{array}$ \\
\hline Ghent system & $\begin{array}{l}-1.103 \\
(0.397)^{* *}\end{array}$ & $\begin{array}{l}-0.521 \\
(0.351)\end{array}$ & $\begin{array}{l}1.021 \\
(0.427)^{*}\end{array}$ & $\begin{array}{l}0.614 \\
(0.385)\end{array}$ & $\begin{array}{l}2.071 \\
(1.033)^{*}\end{array}$ & $\begin{array}{l}0.546 \\
(1.282)\end{array}$ & $\begin{array}{l}2.492 \\
(2.090)\end{array}$ & $\begin{array}{l}-12.224 \\
(5.273)^{*}\end{array}$ & $\begin{array}{l}0.977 \\
(1.394)\end{array}$ & $\begin{array}{l}0.347 \\
(1.881)\end{array}$ \\
\hline SD-federation & & $\begin{array}{l}1.670 \\
(0.786)^{*}\end{array}$ & & $\begin{array}{l}0.800 \\
(0.938)\end{array}$ & & $\begin{array}{l}-8.852 \\
(2.013)^{* * *}\end{array}$ & & $\begin{array}{l}-24.092 \\
(4.702)^{* * * *}\end{array}$ & & $\begin{array}{l}2.797 \\
(3.487)\end{array}$ \\
\hline Public sector & & $\begin{array}{l}6.303 \\
(1.490)^{* * *}\end{array}$ & & $\begin{array}{l}-4.330 \\
(1.768)^{*}\end{array}$ & & $\begin{array}{l}-15.459 \\
(2.891)^{* * *}\end{array}$ & & $\begin{array}{l}-0.937 \\
(4.377)\end{array}$ & & $\begin{array}{l}8.961 \\
(4.461)^{*}\end{array}$ \\
\hline Academic/prof. & & $\begin{array}{l}-5.777 \\
(1.256)^{* * *}\end{array}$ & & $\begin{array}{l}9.990 \\
(1.528)^{* * *}\end{array}$ & & $\begin{array}{l}4.523 \\
(2.710)\end{array}$ & & $\begin{array}{l}60.936 \\
(6.473)^{* * *}\end{array}$ & & $\begin{array}{l}-1.838 \\
(3.561)\end{array}$ \\
\hline Christian & & $\begin{array}{l}1.747 \\
(1.054)\end{array}$ & & $\begin{array}{l}-0.121 \\
(1.251)\end{array}$ & & $\begin{array}{l}-5.631 \\
(3.257)\end{array}$ & & $\begin{array}{l}-13.071 \\
(7.507)\end{array}$ & & $\begin{array}{l}-0.068 \\
(4.837)\end{array}$ \\
\hline Communist & & $\begin{array}{l}3.710 \\
(0.956)^{* * *}\end{array}$ & & $\begin{array}{l}-0.470 \\
(1.077)\end{array}$ & & $\begin{array}{l}-13.152 \\
(2.880)^{* * *}\end{array}$ & & $\begin{array}{l}-37.091 \\
(8.735)^{* * * *}\end{array}$ & & $\begin{array}{l}0.285 \\
(3.812)\end{array}$ \\
\hline $\begin{array}{l}\text { Random inter- } \\
\text { cept variance }\end{array}$ & $\begin{array}{l}0.354 \\
(0.133)^{*}\end{array}$ & $\begin{array}{l}0.158 \\
(0.066)^{*}\end{array}$ & $\begin{array}{l}0.372 \\
(0.144)^{*}\end{array}$ & $\begin{array}{l}0.186 \\
(0.078)^{*}\end{array}$ & $\begin{array}{l}2.761 \\
(1.164)^{*}\end{array}$ & $\begin{array}{l}2.651 \\
(1.288)^{*}\end{array}$ & $\begin{array}{l}11.490 \\
(4.968)^{*}\end{array}$ & $\begin{array}{l}59.861 \\
(32.67)^{*}\end{array}$ & $\begin{array}{l}5.156 \\
(2.201)^{*}\end{array}$ & $\begin{array}{l}5.684 \\
(3.259)^{*}\end{array}$ \\
\hline $\mathrm{N}$ & 67,500 & 65,389 & 41,437 & 40,032 & 26,985 & 26,119 & 25,539 & 24,764 & 24,791 & 23,927 \\
\hline -2Loglikelihood & $-39,400.11$ & $-38,069.75$ & $-25,992.66$ & $-25,038.47$ & $-11,330.27$ & $-10,918.12$ & $-7,787.58$ & $-7,545.76$ & $-7,848.27$ & $-7,497.39$ \\
\hline $\begin{array}{l}\text { Chi-square test } \\
\text { of } r h o=0\end{array}$ & $2,349.5^{* * *}$ & $974.8^{* * *}$ & $1,291.1^{* * *}$ & $690.1^{* * *}$ & $1,553.4^{* * *}$ & $1,303.9^{* * *}$ & $4,960.9 * * *$ & $1,344.2 * * *$ & $2,330.4 * * *$ & $1,378.5^{* * *}$ \\
\hline
\end{tabular}


When specific confederations boost the support of union members for the right

We now turn to the analyses containing the cross-level interactions between the three confederations of interest and union membership. To reiterate, the rationale is to inspect whether union members' voting behaviour is conditioned by the varying strength of social democratic, public sector, and academic professional union federations.

Figure 2 begins with plotting the predicted probabilities for the contrast social democrats versus all other parties (see Table A.1 in online appendix for the full model). The left-hand panel shows that the support for social democracy among union members increases with the membership share in the traditional social democratic peak organisation. If only half of the organized labour force is member of this peak organisation, the predicted support of union members for social democracy is around 30 per cent, while their predicted support increases to more than 50 per cent if everybody is member of the social democratic umbrella (as in Austria). A similar and somewhat stronger pattern occurs in the middle panel which plots the interaction union member*public sector confederation.

The opposite is true if we look at the right-hand panel. The support for social democracy among organized managers more than halves from 46 to 19 per cent across the observed values of the membership shares in the academic/professional unions. Accordingly, it is not easy for social democracy to mobilize middle class voters if these are organized under an independent academic white-collar organisation. By contrast, strong social democratic confederations boost the support of union members for social democracy, as well as public sector confederations. These findings corroborate Hypothesis 3 and give some first support for Hypothesis 4 which we now investigate further in detail by presenting the results for the party contrasts centre-right vs. social democracy and greens vs. social democracy. 
Figure 2: Predicted vote share for Social Democracy among union members (y-axis) over membership shares in three union confederations

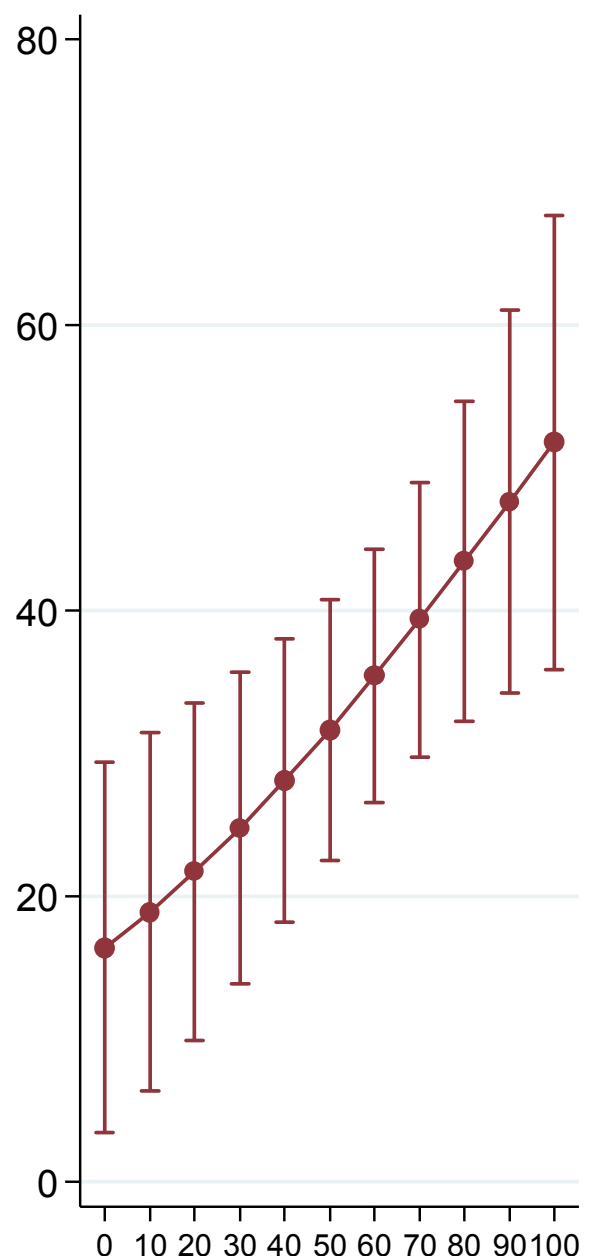

Share of union members organised in social democratic federation, \%

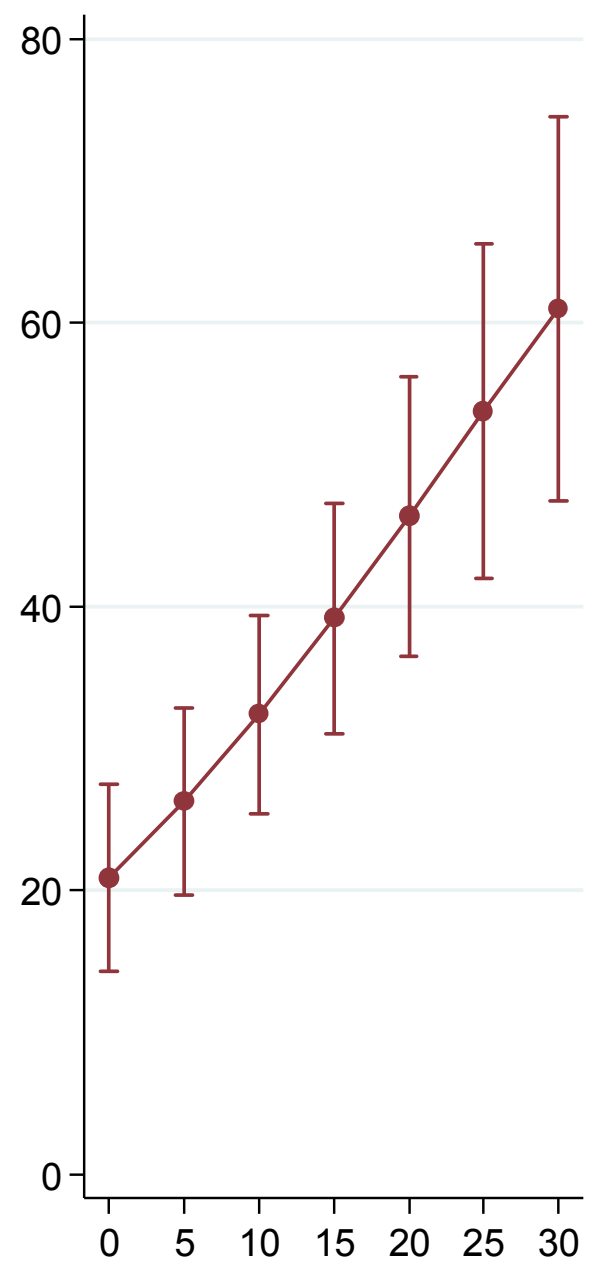

Share of union members organised in public sector federation, \%

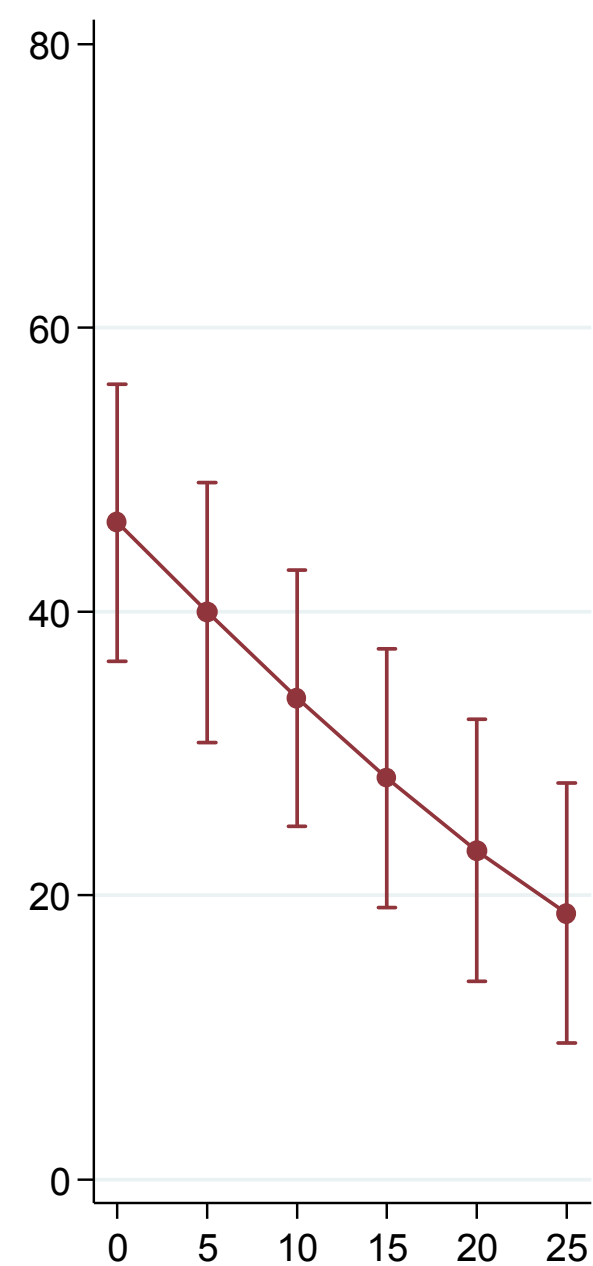

Share of union members organised in academic/professional federation, \%

Source: Predicted probabilities based on Models M2a-M2c in Table A1 (online appendix). Left-hand panel: low educated unionized production worker; Middle panel: female unionized socio-cultural specialist with tertiary education; Right-hand panel: unionized manager with tertiary education (all 45 years). 
Figure 3 presents the probabilities for the contrast centre-right versus social democracy. The left-hand side shows surprisingly that support for centre-right parties among union members does not diminish with increasing strength of traditional social democratic unions a result that already occurred in Model 4 in Table 1. By contrast, the results for the middle panel indicate as previously that the public sector federations work as a mobilisation base for social democracy.

Finally, the right-hand panel shows that strong academic union federations increase the vote for the centre-right vis-à-vis social democracy. A unionized manager has a probability of around 28 percent to vote for the centre-right if there is no independent academic federation (as is the case in Austria), but has a probability of more than 70 percent to support the centreright if the academic confederations organize one fourth of all union members (our observed maximum in Finland). This provides strong support for Hypothesis 4 in case of centre-right parties and indicates that social democratic parties have mobilization problems if middle class professions are organized under separate academic federations.

Next, we turn to the contrast green parties vs. social democracy in Figure 4. The lefthand panel shows that green parties have a structural disadvantage among union members if strong social democratic unions are present. The same goes for the effect of membership in public sector unions shown in the middle panel. In the right-hand panel, by contrast, the support for the Greens among organized socio-cultural specialists further increases with the membership share in academic/professional unions. This is contrarily to the results for the centre-right not significant, but provides some more tentative support for our Hypothesis 4 . 
Figure 3: Predicted vote share for Centre-right vs. Social Democracy among union members (y-axis) over membership shares in three union confederations

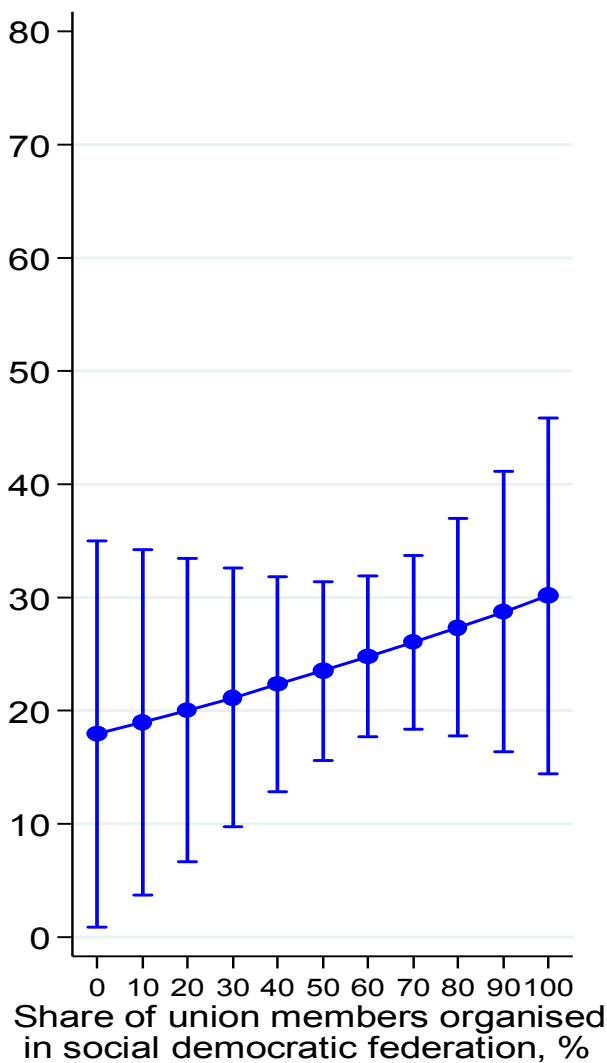

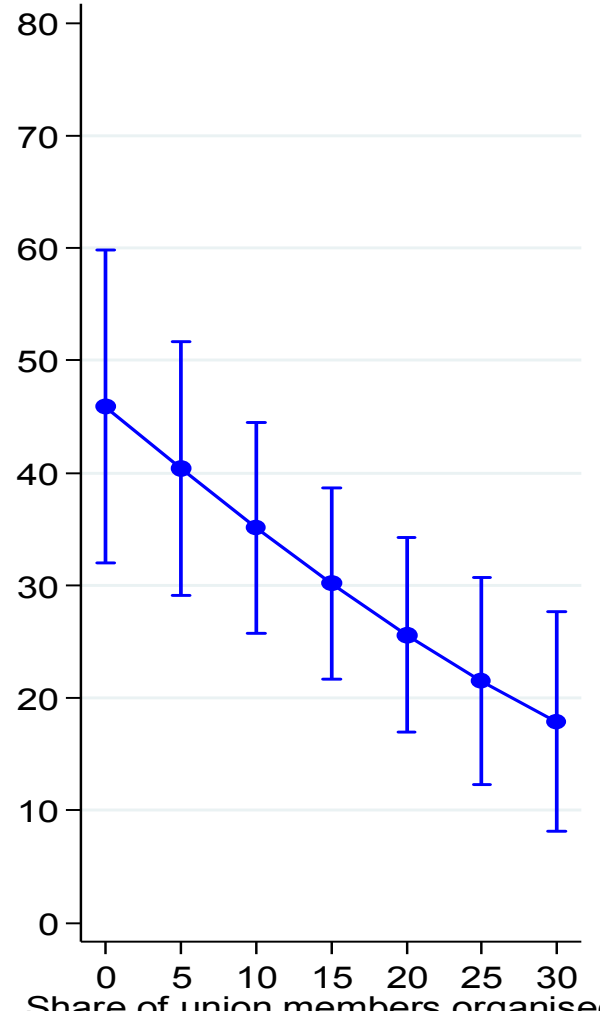

Share of union members organised in public sector federation, \%

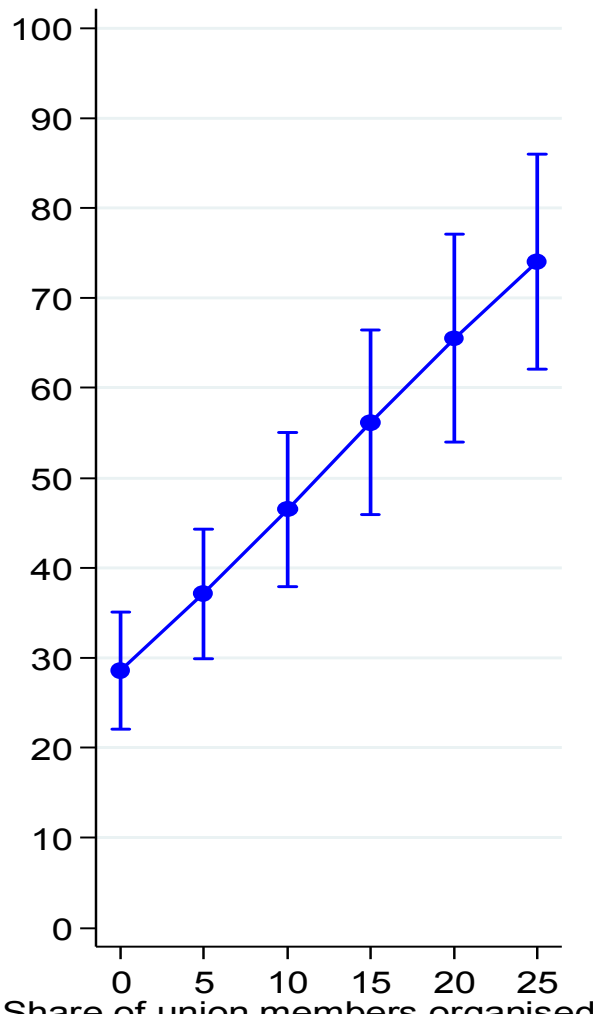
in academic/professional federation, \%

Source: Predicted probabilities based on Models 4a-4c in Table A2 (online appendix). Left-hand panel: low educated unionized production worker; Middle panel: female unionized socio-cultural specialist with tertiary education; Right-hand panel: unionized manager with tertiary education (all 45 years). 
Figure 4: Predicted vote share for Greens vs. Social Democracy among union members (y-axis) over membership shares in three union confederations

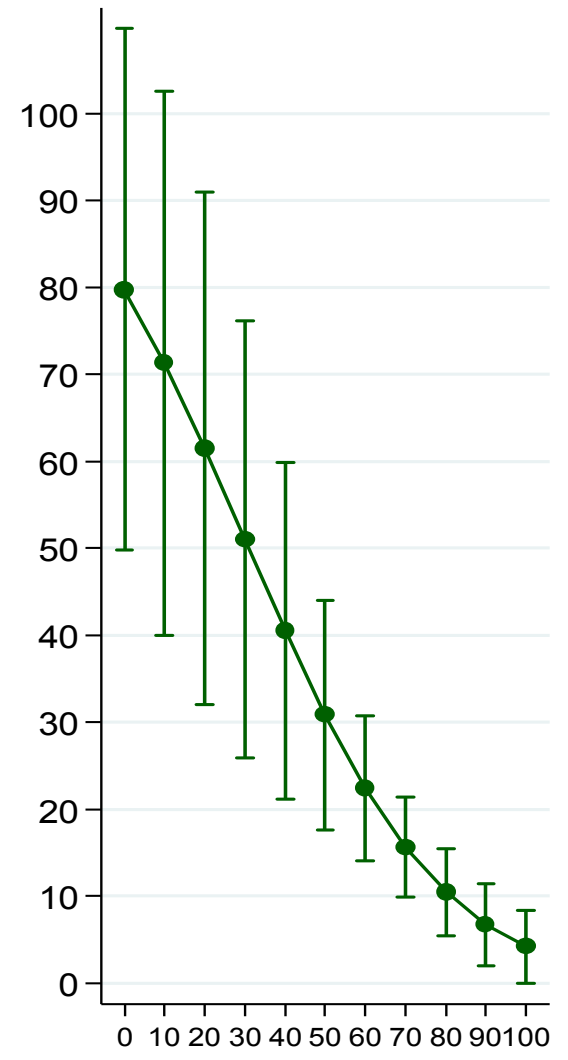

Share of union members organised in social democratic federation, \%

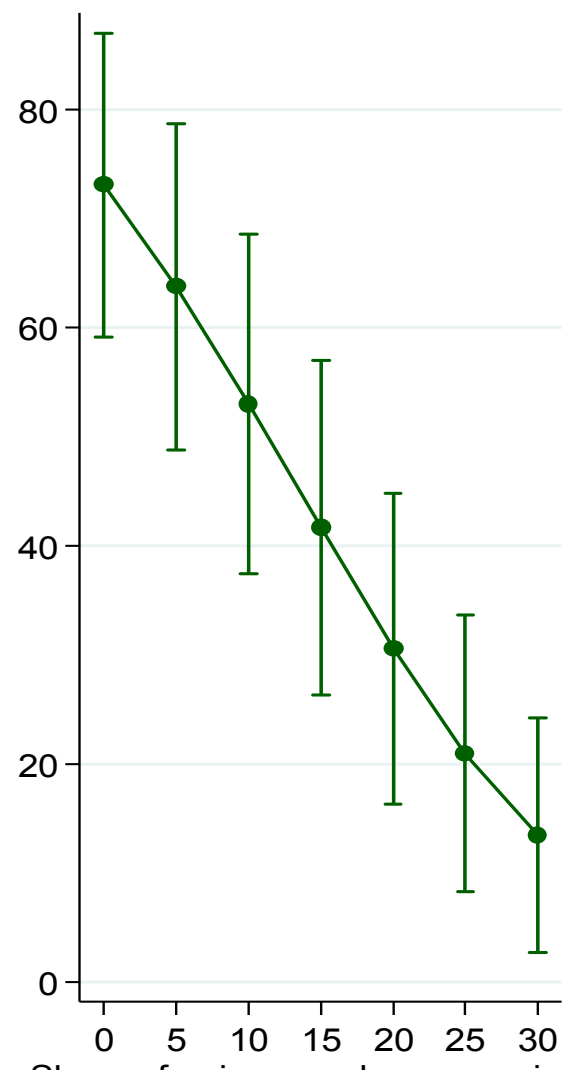

Share of union members organised in public sector federation, \%

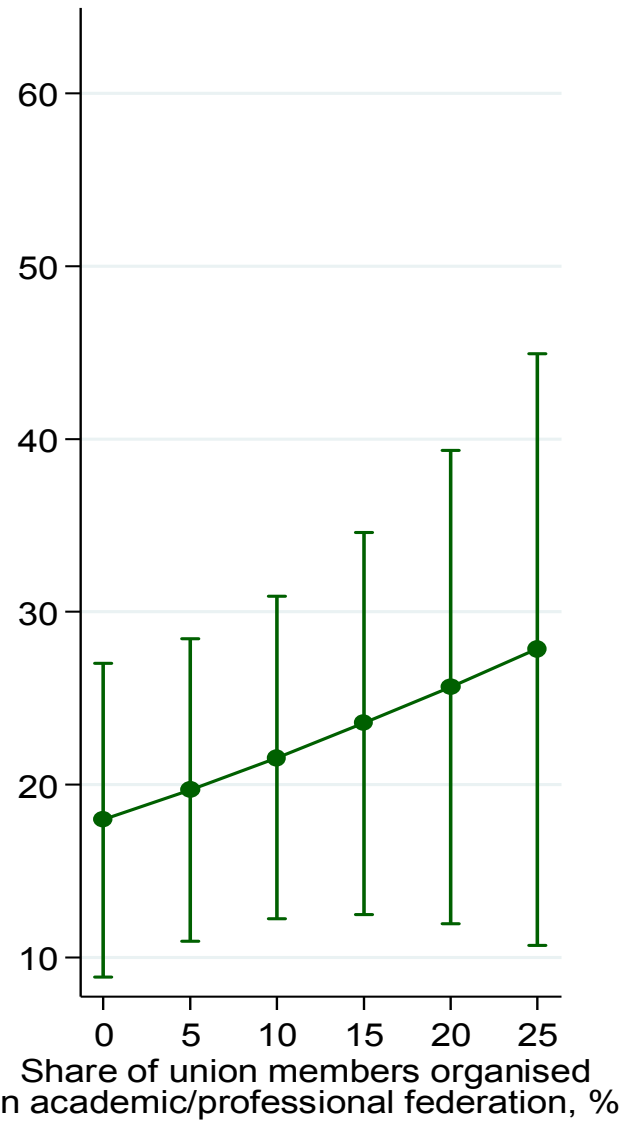

Source: Predicted probabilities based on Models M6a-M6c in Table A3 (online appendix). Left-hand and right-hand panel: unionized manager with tertiary education; Middle panel: female unionized socio-cultural specialist with tertiary education (all 45 years). 


\section{Case study: Party choice among Swedish union members 1985-2010}

We turn to the in-depth analysis of the Swedish case in the period 1985-2010. To reiterate, the following results present predicted probabilities from a multinomial logit model with the RiksSOM surveys 1985-2010 for election years. ${ }^{8}$ We show the predicted vote choice in percent obtained from the interaction trade union confederation membership*election year for the Swedish parties. The results for the radical right base on a model for a shorter time period since this party family emerged in 1991 with the New Democracy surpassing the threshold.

Beginning with LO member's vote choice in Figure 5a, we can see that the SAP has lost around 10 percent support among LO members since 1985 - the confederation traditionally affiliated with the SAP. The SAP is nevertheless the dominating party here as it still gains more than every second LO member in 2010, while its support among unorganized voters never exceeds 30 percent in the whole period. This further confirms our Hypothesis 1 on the positive effects of union membership in traditional blue-collar federation for social democratic vote choice. Another supplementary analysis containing interactions between the membership share for the LO and LO membership (available on request from the authors) replicates this finding and also reveals that the effect of being an LO member on supporting the SAP decreases with the falling membership share of the LO. This resembles our cross-country findings from Figure 2 and confirms Hypothesis 3.

Furthermore, Figure 5a also reveals that the conservative Moderate Party has become rival for the SAP among LO members. This is consistent with the cross-country study which showed that the support for centre-right parties among union members did not diminish with increasing strength of social democratic confederations. However, the pattern is clearer in the case of the Swedish Left Party, since it increases its vote shares only among LO members. This is in line with Hypothesis $2 b^{9}$ and previous research which demonstrated that the radical left has gained strength among disillusioned social democratic constituencies (Arndt 2013, Karreth, Polk \& Allen 2013). Finally, tentative results for the radical right for three elections (figure 5b) suggest a further competition for the social democrats. The data used only distinguished the radical right's

\footnotetext{
${ }^{8}$ See the online appendix for the full models and further details.

${ }^{9}$ In all our analyses for Sweden, the Left Party is the only party that does not significantly differ from the SAP in the voting behaviour of union members (LO).
} 
voters from other parties in 1991 (New Democracy, ND) and 2006/2010 (Sverigedemokraterna, SD). While the ND had an indistinguishable support among the four categories of our independent variable in 1991, the SD shows significantly stronger support among LO members and unorganized voters compared to members of the two white-collar federations.

Figure 5a: Predicted Vote Shares Among Union Members, Elections for Swedish Riksdag 1985-2010

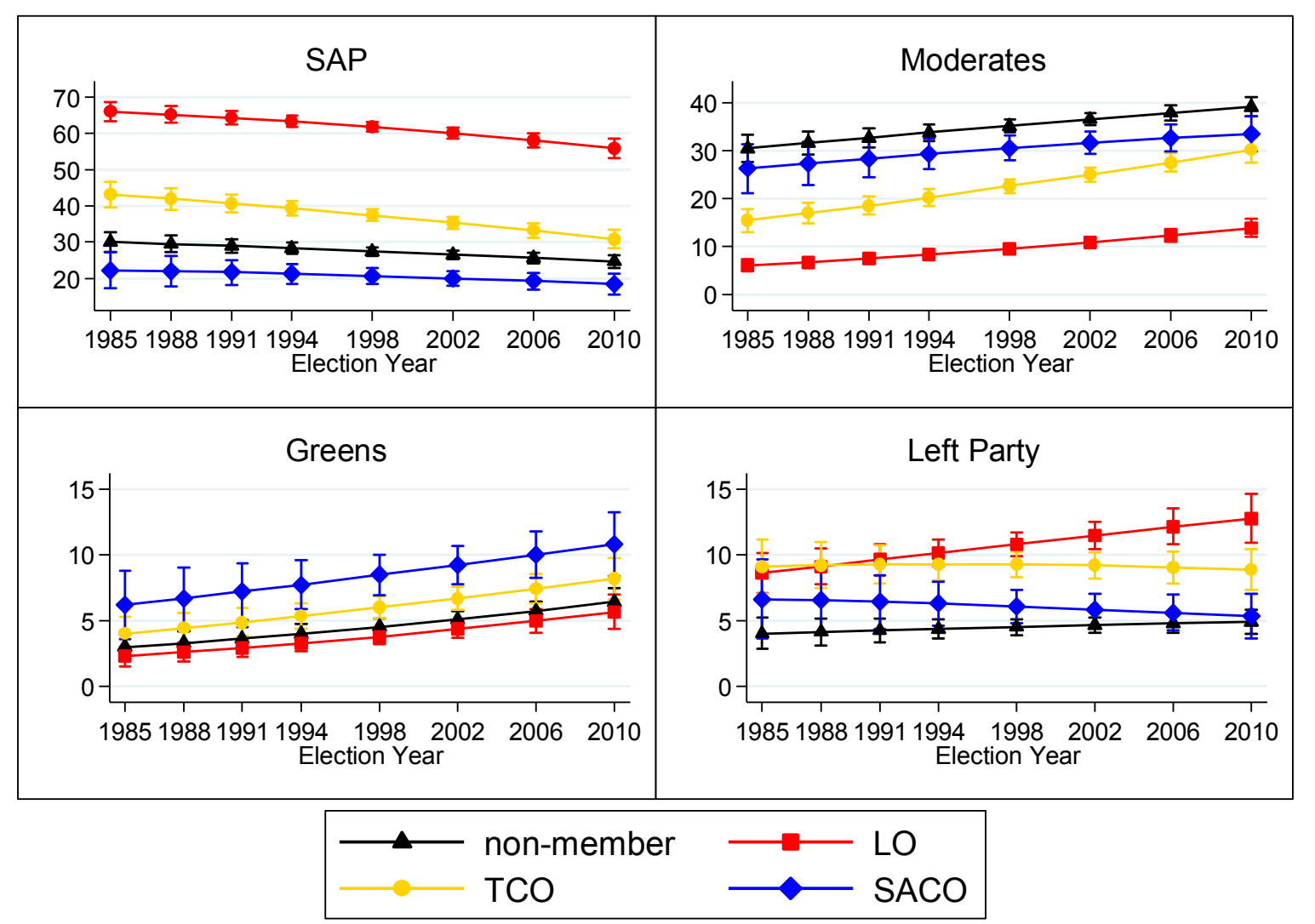

Source: Multinomial logit models with Riks-SOM surveys 1985-2010 ( $\mathrm{N}=14.764)$. Y-axis shows predicted vote shares for parties in percent. Models include class, age, education, private-public sector and sex as controls and fixed at means or modes.

Does the SAP succeed in broadening its supporter base in order to compensate for the loss of LO support and the declining share of LO members among the organized labour force? In line with hypothesis 4, our cross-country analysis has shown that independent academic and professional union confederations do not always bring an advantage for social democratic parties. The Swedish case demonstrates the same logic for the professional Saco confederation. The support of Saco members for the SAP was never strong and even significantly fell below the 
SAP's support among unorganized voters. In contrast, the Saco members have reinforced their affiliation with the conservative Moderates and the difference in support to the SAP has become significant after 1994. The Greens have also constantly gained support among Saco members. The Greens and the Liberal People's Party (Figure 5b) are also the only parties whose support is constantly strongest among Saco members vis-à-vis all other confederations and non-members. These results yield further support for our fourth hypothesis that academic and professional unions impede a social democratic mobilization of the new middle class. A further notable result is the internal reallocation of Saco support within the bourgeois bloc where the Liberal People's Party has constantly lost support to the benefit of the Moderates, the Centre Party, and the Christian Democrats.

Figure 5b: Predicted Vote Shares Among Union Members, Elections for Swedish Riksdag 1985-2010

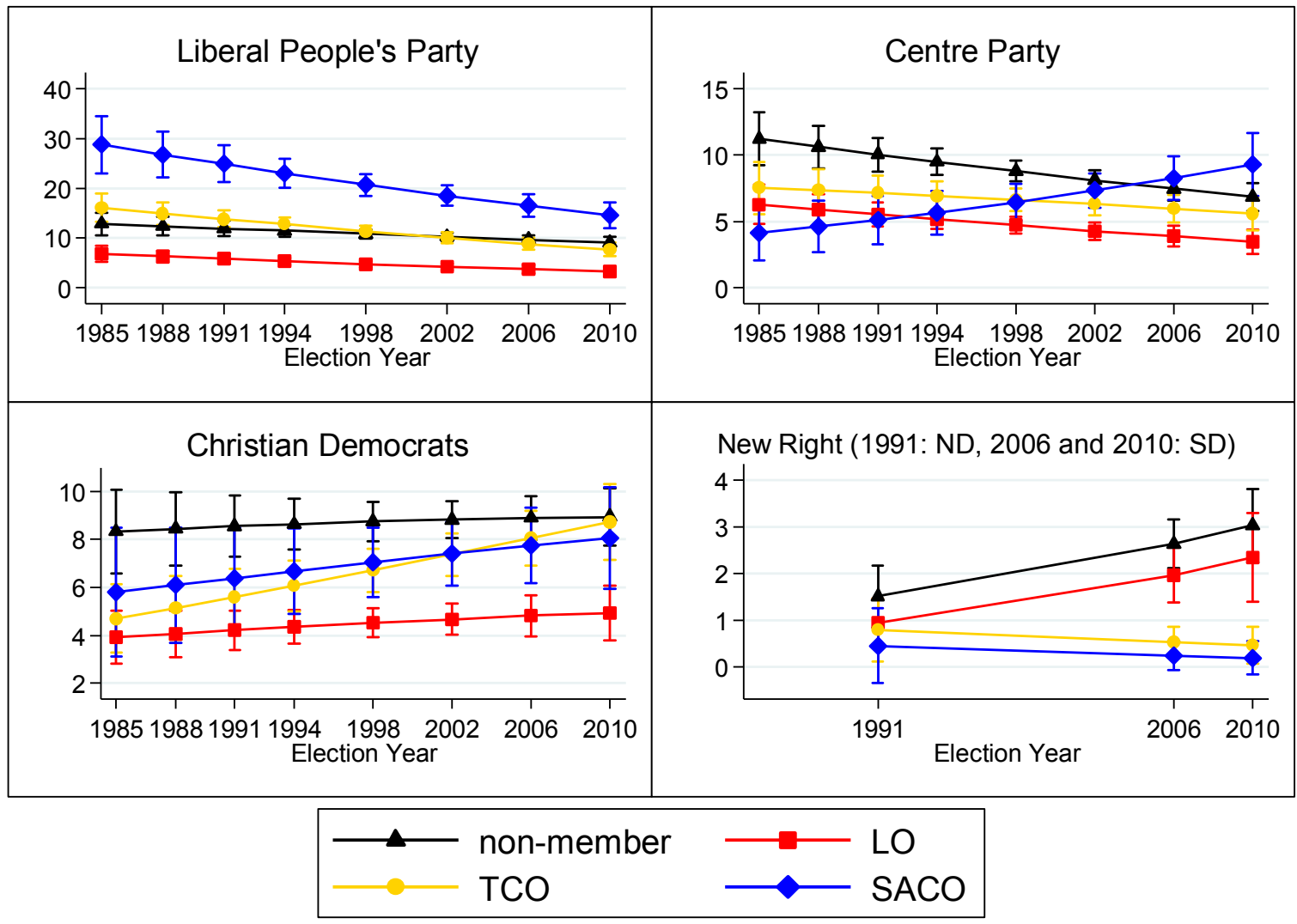

Source: Multinomial logit models with Riks-SOM surveys 1985-2010 (N=14.764). Y-axis shows predicted vote shares for parties in percent. Models include class, age, education, private-public sector and sex as controls and fixed at means or modes. ND: Ny Demokrati, SD: Sverigedemokraterna. 
A somewhat different pattern is found for the members of the confederation TCO which organizes twice as much members as Saco. Similarly to LO members, the SAP has lost support among TCO members, while the Greens and particularly the Moderates have gained support. After 2002, the difference in Moderate support among the TCO is no longer statistically different from the Saco members. However, the SAP is throughout the whole period the strongest party among TCO members and the difference to the Moderates is statistically significant at the 95 percent level for all years except 2010. The three left parties (SAP, Greens, and Left Party) are also the parties that are consistently stronger among TCO members compared to unorganized voters, while the pattern for the bourgeois parties is the opposite. This confirms to some degree the finding from the 16 country analysis that public sector/white-collar unions are beneficial for social democracy and the left in general.

We have shown here the party preferences of the "average" union member in three different confederations. In order to show that the presence of separate white-collar confederations really makes a difference at the individual level, we further interacted union confederation membership with social class (see Appendix B). Let's take as example a person from the lower salariat which forms an ideal recruitment target for white-collar unions. Indeed, this social class is predominantly organized in the TCO with 37\% (average for the entire period), but also to some extent in the Saco (19\%) and in LO (6\%). The predicted probabilities (left-hand panel of Figure B1 in Appendix B) show that members of the lower salariat have a strong propensity to vote for the SAP and a weak propensity to vote for the Moderates if organized under LO. The pattern is completely reversed if the person is organized under Saco - he/she votes in a similar way as a non-member. This is not the case if the person is organized under the other white-collar confederation. Among the lower salariat organized under TCO, the SAP still has a significant advantage over the Moderates, but the pattern is weaker compared to the LO. These findings suggest the existence of context effects beyond the pure differences in who is the "average" union member $^{10}$.

\footnotetext{
${ }^{10}$ Further analyses on Austria (see Appendix B) also shed light on this contextual effect. The members of the ÖGB confederation (indeed all union members in this country) have a close level of support for the social democratic party as the members of the LO confederation in Sweden.
} 


\section{Conclusion}

This article has investigated the electoral behaviour of trade union members in a comparative perspective. We have argued that union membership at the individual level is still beneficial for social democracy at the ballots. However, we have pleaded at the same time to pay more attention to the diversity of trade union landscapes. We therefore argued that union membership as a resource for social democracy depends on the union structure.

On the one hand, our findings based on a comparative study of 16 European countries reveal a strong left-right structuration in the party preferences of union members. Despite difficult relationships between the two arms of the labour movement, union members are still more supportive of social democratic parties. Radical left parties benefit equally from the support of union members, while the Greens stay slightly behind. Organized workers are less likely to support centre-right parties, and even less likely to support the radical right-wing parties. While several studies over the last years pointed to the capacity of radical right-wing parties to gain new support among the traditional constituencies of the left (working class), the same is not true if we consider the organizational element of the class cleavage. This suggests that organized workers are less likely be "disturbed" by the cultural appeals of the radical right (e.g. on immigration) which has proved to be decisive in the support for this party family (e.g. Oesch 2008a, Ivarsflaten 2005).

On the other hand, our findings showed that the support of union members varies depending on the union structure and can take unexpected forms. It is particularly the presence of academic/professional confederations that matters. The comparative study indicated that bourgeois and to a lesser extent Green parties gain momentum among union members in countries with strong separate professional confederations. In contrast, the presence of public/white-collar confederations clearly fosters the support for social democracy. Based on detailed information on the affiliation into different confederations, the case study on Sweden permitted to further illustrate the different party preferences of union members and their overtime variation. In the period 1985-2010, the Swedish social democratic party has constantly lost support among members of the blue-collar confederation LO. The SAP is in great difficulty in mobilising Saco members who build the strongholds of the conservative Moderates, the Liberals and the Greens. Again, the non-social democratic orientation of union members seems to be 
specific to the members of academic/professional confederations. The members of the TCO white-collar confederation display an intermediate level of support for the SAP.

Our article has focused on the vote choice of union members and how it varies across party systems and trade union contexts given the lack of current knowledge on this matter. Further research should devote more attention to the underlying mechanisms that we did not test. Particularly, further research should show what exactly makes union members more likely to stick to the left parties and to dislike the radical right, also by including parties' and unions' positions on both economic and cultural issues as a further conditioning variable. We should also more precisely analyse why specific white-collar confederations (e.g. Saco) do not foster the support for social democracy. Our results are ambivalent for social democracy in the context of the growth of white-collar employment. The membership in a white-collar confederation such as TCO in Sweden does not make such a big difference for social democracy in terms of electoral mobilization as compared to a "traditional" blue-collar confederation. The prospects are less good among members of professional and academic confederations where the deployment of the values of the labour movement seems to be more a challenge. 


\section{Appendix}

Table A.1: Classification of union confederations in 16 countries after 2001

\begin{tabular}{|c|c|c|c|c|c|c|}
\hline & $\begin{array}{l}\text { Social } \\
\text { Democratic }\end{array}$ & $\begin{array}{l}\text { Public } \\
\text { Sector/White } \\
\text {-collar }\end{array}$ & $\begin{array}{l}\text { Academic/ } \\
\text { professional }\end{array}$ & Christian & Communist & Other \\
\hline Austria & ÖGB & - & - & - & - & - \\
\hline Belgium & FGTB & - & - & $\mathrm{CSC}$ & - & CGLSB \\
\hline Denmark & LO & FTF & $\mathrm{AC}, \mathrm{FR} / \mathrm{LH}$ & - & - & - \\
\hline Finland & SAK & STTK & AKAVA & - & - & - \\
\hline France & CFDT, FO & FEN/UNS & CGC & CFTC & CGT & - \\
\hline Germany & DGB & DBB & ULA & CGB & - & - \\
\hline Ireland & ICTU & - & - & - & - & - \\
\hline Italy & UIL & - & - & CSIL & CGIL & - \\
\hline Luxembourg & OGBL & CGFP & FEP/FITC & LCGB & - & - \\
\hline $\begin{array}{l}\text { The } \\
\text { Netherlands }\end{array}$ & FNV & - & MHP & $\mathrm{CNV}$ & - & - \\
\hline Norway & LO & UNIO & $\mathrm{AF}$ & - & - & YS/YH \\
\hline Portugal & UGT-P & - & (USI) & - & CGTP-IN & - \\
\hline Spain & UGT & CSI-CSIF & - & USO & CC.OO & $\begin{array}{l}\text { CGT (+ } \\
\text { nationalist } \\
\text { confeds) }\end{array}$ \\
\hline Sweden & LO & TCO & SACO & - & - & - \\
\hline Switzerland & SGB & - & - & $\begin{array}{l}\text { Travail } \\
\text { Suisse }\end{array}$ & - & - \\
\hline UK & TUC & - & - & - & - & - \\
\hline
\end{tabular}

Source: Own classification based on Visser's (2013). We used the variables SCf11 to SCf18. Notes: The category "other" applies to all other independent and non-classifiable confederations if not mentioned otherwise; the merger of non-SGB unions in Switzerland requires only two categories in Swiss case after 2001, there would be more confederations if using data before 2002; the German DAG is not included as public sector as it merged into VERDI and joined the DGB in 2001/02; data for Portuguese USI are missing. 
Table A.2: Classification of parties in 16 countries after 2001

\begin{tabular}{|c|c|c|c|c|c|}
\hline & $\begin{array}{l}\text { Social } \\
\text { Democratic }\end{array}$ & $\begin{array}{l}\text { Main Centre- } \\
\text { right }\end{array}$ & $\begin{array}{l}\text { Green/left- } \\
\text { libertarian }\end{array}$ & Radical Left & Radical Right \\
\hline Austria & SPÖ & ÖVP & Grüne & - & FPÖ, BZÖ \\
\hline Belgium & SP.A/PS & $\begin{array}{l}\mathrm{CVP} / \mathrm{CD} \\
\mathrm{PSC} / \mathrm{CDH}\end{array}$ & Agalev/Ecolo & PvdA/PTB-UA & VB \\
\hline Denmark & $\mathrm{S}$ & Venstre & $\mathrm{SF}$ & Enhedslisten & $\mathrm{DF}$ \\
\hline Finland & SDP & Centre Party & Green League & $\begin{array}{l}\text { Left Alliance, } \\
\text { Communists }\end{array}$ & True Finns \\
\hline France & PS & UMP & Les Verts & PC, LCR, LO & FN, MNR \\
\hline Germany & SPD & $\mathrm{CDU} / \mathrm{CSU}$ & B'90-Grüne & Die Linke & $\begin{array}{l}\text { Republikaner, } \\
\text { (NPD/DVU) }\end{array}$ \\
\hline Ireland & Labour & Fianna Fáil & Green Party & $\begin{array}{l}\text { Sinn Fein, } \\
\text { Socialist Party, } \\
\text { Left Alliance }\end{array}$ & - \\
\hline Italy & La Margarita & Forza Italia & Verdi & Communists & AN, Lega Nord \\
\hline Luxembourg & LSAP & CSV & Déi Gréng & La Gauche & ADR \\
\hline The Netherlands & PvdA & CDA & Groen-Links & SP & PVV, LPF, LN \\
\hline Norway & DNA & Høyre & SV & Rødt & FrP \\
\hline Portugal & PS & PSD & $\mathrm{CDU}$ & Bloco de Esquerda & National Renovador \\
\hline Spain & PSOE & PP & - & IU & - \\
\hline Sweden & SAP & Moderaterna & Miljöpartiet & Vänsterpartiet & Sverigedemokraterna \\
\hline Switzerland & SPS & FDP & GPS & $\begin{array}{l}\text { Partei der Arbeit } \\
\text { der Schweiz }\end{array}$ & $\begin{array}{l}\text { SVP, Schweizer } \\
\text { Demokraten } \\
\text { FDS }\end{array}$ \\
\hline$\overline{\mathrm{UK}}$ & Labour & Conservative & Green Party & - & (UKIP) \\
\hline
\end{tabular}

Source: Own classification. Parentheses indicate too few observations for statistical analysis. 
References

Afonso, A. 2015, "Choosing whom to betray: populist right-wing parties, welfare state reforms and the trade-off between office and votes", European Political Science Review, vol. 7, no. 2, pp. 271 $-292$.

Allern, E.H. \& Bale, T. 2012, "Political parties and interest groups : Disentangling complex relationships", Party Politics, vol. 18, no. 1, pp. 7-25.

Allern, E.H., Aylott, N. \& Christiansen, F.J. 2007, "Social Democrats and trade unions in Scandinavia: The decline and persistence of institutional relationships", European Journal of Political Research, vol. 46, no. 5, pp. 607-635.

Arndt, C. 2014, "Social democracy's mobilization of new constituencies: The role of electoral systems", Party Politics, vol. 20, no. 5, pp. 778-790.

Arndt, C. 2013, The Electoral Consequences of Third Way Welfare State Reforms, Amsterdam University Press, Amsterdam.

Arzheimer, K. 2013, "Working-class parties 2.0? Competition between centre-left and extreme right parties" in Class Politics and the Radical Right, ed. J. Rydgren, Routledge, London; New York, pp. 75-90.

Bartolini, S. \& Mair, P. [2007] 1990, Identity, Competition and Electoral Availability, ECPR Press, Colchester.

Berry, W.D., DeMeritt, J.H. \& Esarey, J. 2010, "Testing for interaction in binary logit and probit models: is a product term essential?", American Journal of Political Science, vol. 54, no. 1, pp. 248-266.

Béthoux, E., Desage, G., Mias, A. \& Pélisse, J. 2013, Sociologie d'un syndicalisme catégoriel. La CFECGC ou la fin d'une exception ?, Armand Colin, Paris.

Blackburn, R. \& Prandy, K. 1965, "White-Collar Unionization: A Conceptual Framework", The British journal of sociology, vol. 16, no. 2, pp. 111-122.

Brambor, T., Clark, W.R. \& Golder, M. 2006, "Understanding interaction models: Improving empirical analyses", Political Analysis, vol. 14, no. 1, pp. 63-82.

Crompton, R. 1976, "Approaches to the Study of White-Collar Unionism", Sociology, vol. 10, no. 3, pp. 407-426.

Ebbinghaus, B., Göbel, C. \& Koos, S. 2011, "Social capital, 'Ghent' and workplace contexts matter: Comparing union membership in Europe", European Journal of Industrial Relations 17(2), vol. 17 , no. 2 , pp. 107-124.

Ebbinghaus, B. 2000, "Austria" in Trade unions in Western Europe since 1945, ed. B. Ebbinghaus and Jelle Visser, Grove's dictionaries ; Macmillan, New York, Basingstoke etc., pp. 77-110. 
Ebbinghaus, B. 1995, "The Siamese Twins: Citizenship Rights, Cleavage Formation, and Party-Union Relations in Western Europe", International Review of Social History, vol. 40, no. Supplement 3, pp. 51-89.

Ebbinghaus, B. \& Visser, J. 2000, Trade Unions in Western Europe since 1945, Grove's dictionaries ; Macmillan, New York, Basingstoke, etc.

Evans, G. \& De Graaf, N.D. 2013, "Explaining Cleavage Strength: The Role of Party Positions" in Political Choice Matters. Explaining the Strength of Class and Religious Cleavages in CrossNational Perspective, eds. G. Evans \& N.D. De Graaf, Oxford University Press, Oxford.

Gingrich, J. \& Häusermann, S. 2015, "The decline of the working-class vote, the reconfiguration of the welfare support coalition and consequences for the welfare state", Journal of European Social Policy, vol. 25, no. 1, pp. 50-75.

Gumbrell-McCormick, R. \& Hyman, R. 2013, Trade unions in Western Europe : hard times, hard choices, Oxford University Press, Oxford.

Häusermann, S., Picot, G. \& Geering, D. 2013, "Review Article: Rethinking Party Politics and the Welfare State-Recent Advances in the Literature", vol. 43, no. 1, pp. 221-240.

Höpflinger, F. 1980, Die anderen Gewerkschaften. Angestellte und Angestellenverbände in der Schweiz, eco-verlag Zürich, Zürich.

Ivarsflaten, E. 2005, "The vulnerable populist right parties: No economic realignment fuelling their electoral success", European Journal of Political Research, vol. 44, no. 3, pp. 465-492.

Karreth, J., Polk, J.T. \& Allen, C.S. 2013, "Catchall or Catch and Release? The Electoral Consequences of Social Democratic Parties' March to the Middle in Western Europe", Comparative Political Studies, vol. 46, no. 7, pp. 791-822.

Kitschelt, H. 1994, The Transformation of European Social Democracy, Cambridge University Press, Cambridge ; New York etc.

Kjellberg, A. 2013, Union density and specialist/professional unions in Sweden, Studies in Social Policy, Industrial Relations, Working Life and Mobility. Research Reports 2013: 2 (updated 2014), Lund University.

Mosimann, N. \& Pontusson, J. 2014, "Bounded communities of solidarity: Union membership and preferences for redistribution". Paper presented at the UNIGE-Princeton workshop: "Democratic representation in an era of rising economic inequality", 23-24 June 2014.

Nachtwey, O. \& Spier, T. 2007, "Political Opportunity Structures and the Success of the German Left Party in 2005", Debatte, vol. 15, no. 2, pp. 123-154.

OECD.Stat 2013, OECD Statistics, Available at https://stats.oecd.org/Index.aspx?DataSetCode $=\cup \quad D \quad$, Source: OECD and J.Visser, ICTWSS database, version 3.0. 
Oesch, D. 2008a, "Explaining Workers' Support for Right-Wing Populist Parties in Western Europe: Evidence from Austria, Belgium, France, Norway and Switzerland", International Political Science Review, vol. 29, no. 3, pp. 349-373.

Oesch, D. 2006, Redrawing the Class Map. Stratification and Institutions in Britain, Germany, Sweden and Switzerland, Palgrave Macmillan, London.

Parsons, N. 2015, "Left parties and trade unions in France", French Politics, vol. 13, no. 1, pp. 63-68.

Pasture, P. 2002, "The role of religion in Labour History" in Class and other identities : gender, religion and ethnicity in the writing of European labour history, eds. L. Heerma van Voss \& M. Van der Linden, Berghahn Books, New York etc., pp. 101-132.

Pontusson, J. 2013, "Unionization, Inequality and Redistribution", British Journal of Industrial Relations, vol. 51, no. 4, pp. 797-825.

Quinn, T. 2010, "New Labour and the Trade Unions in Britain", Journal of Elections, Public Opinion \& Parties, vol. 20, no. 3, pp. 357-380.

Rennwald, L. 2015, Partis socialistes et classe ouvrière. Ruptures et continuités du lien électoral en Suisse, en Autriche, en Allemagne, en Grande-Bretagne et en France (1970-2008), Editions Alphil-Presses universitaires suisses, Neuchâtel.

Rovny, J. 2013, "Where do radical right parties stand? Position blurring in multidimensional competition", European Political Science Review, vol. 5, no. 1, pp. 1-26.

Sassoon, D. 1996, One hundred years of socialism : the West European left in the twentieth century, Tauris, London.

Streeck, W. \& Hassel, A. 2003, "Trade unions as political actors" in International Handbook of Trade Unions, eds. J.T. Addison \& C. Schnabel, Edward Elgar, Northampton, pp. 335-365.

Visser, J. 2013, Data Base on Institutional Characteristics of Trade Unions, Wage Setting, State Intervention and Social Pacts, 1960-2011 (ICTWSS), Version 4.0, Amsterdam Institute for Advanced Labour Studies, University of Amsterdam. Available at http://www.uva-aias.net/208, Amsterdam.

Weibull, L., Holmberg, S., Oscarsson, H.E., Martinsson, J. \& Markstedt, E. 2014, Super-Riks-SOM 19862012, SOM-institutet, www.som.gu.se, Göteborgs Universitet. 